\section{CUITURE \&SOCIETY JOURNAL OF ANTHROPOLOGICAL REEEARCH}

Culture \& Society: Journal of Anthropological Research

VOL. 1 NO. 3 MARET 2020

http://culture.ppj.unp.ac.id

Email: culture@ppj.unp.ac.id

ISSN: 2686-343X (E-ISSN) 2686-3421 (P-ISSN)

DOI: https://doi.org/10.24036/csjar.v1i3.37

\title{
Makna Upacara Kematian Malapeh-lapeh bagi Masyarakat Nagari Taluak Pesisir Selatan
}

\author{
Besfi Apri Yolanda ${ }^{1}$,Emizal Amri ${ }^{2}$, Erda Fitriani ${ }^{3}$ \\ ${ }^{1}$ SMAN 2 Bukit Batu Riau \\ ${ }^{2,3}$ Universitas Negeri Padang \\ Email : besfiAY@gmail.com, emizal_amri@yahoo.com, erdafitriani@fis.unp.ac.id
}

\begin{abstract}
Abstrak
Penelitian ini bertujuan untuk menjelaskan makna upacara kematian malapeh-lapeh bagi masyarakat Nagari Taluak Pesisir Selatan. Upacara kematian merupakan bagian penting dalam lingkaran hidup manusia. Kematian tidak hanya merupakan proses peralihan manusia yang berpindah kehidupan ke alam roh, namun bagi suatu masyarakat terdapat makna yang dalam, sehingga upacara ini sangat penting dilaksanakan. Masyarakat nagari melaksanakan rangkaian upacara kematian yang biasa dilakukan oleh masyarakat Islam Minangkabau, akan tetapi sedikit berbeda dengan daerah lain yaitu adanya upacara malapeh lapeh. Penelitian ini merupakan penelitian etnografi dengan teknik pemilihan informan dilakukan melalui purposive sampling yang berjumlah 30 orang. Data dikumpulkan melalui observasi partisipasi, wawancara mendalam dan studi dokumen. Data yang diperoleh dianalisis mengacu pada model analisis interpretatif yang dikembangkan oleh Clifford Geertz. Hasil penelitian makna dari upacara malapeh-lapeh adalah, sebagai penghargaan terhadap ninik mamak, nilai solidaritas sosial dalam masyarakat dan identitas masyarakat Nagari.
\end{abstract}

Kata kunci: Interpretivisme Simbolik, Makna simbol, Malapeh-lapeh, Upacara kematian

\section{Abstract}

This study aims to explain the meaning of the Malapeh-Lapeh Death Ceremony for the people of Nagari Taluak Pesisir Selatan. Death ceremonies are an important part of the circle of human life. Death is not only a process of human transition that moves life to the spiritual realm, but for a society there is a deep meaning, so this ceremony is very important to be carried out. The nagari community carries out a series of death ceremonies that are usually carried out by the Minangkabau Islamic community, but it is slightly different from other regions, namely the existence of the Malapeh Lapeh ceremony. This research is an ethnographic research with informant selection technique carried out through purposive sampling, amounting to 30 people. Data was collected through participant observation, in-depth interviews and document study. The data obtained were analyzed referring to the interpretive analysis model developed by Clifford Geertz. The research results of the meaning of the Malapeh-Lapeh ceremony are an understanding of life after death, as an appreciation of the status of the deceased, the value of social solidarity in society and the identity of the Nagari community.

Keywords: Death Ceremony, Malapeh-lapeh, Symbolic Interpretivism, Symbol Meaning

\begin{tabular}{l|l|l} 
Received: March 10, 2020 & Revised: March 30, 2020 & Published: March 31, 2020 \\
\hline
\end{tabular}




\section{Pendahuluan}

Setelah mayat dikuburkan, biasanya masyarakat Islam Minangkabau melaksanakan tradisi yang disebut dengan bilangan hari, yaitu mandua hari, manigo hari, manujuah hari, ampek puluah hari dan bahkan manyartuih hari. Namun sedikit berbeda dengan masyarakat Nagari Taluak Kabupaten Pesisir Selatan Sumatera Barat, masyarakat ini juga melaksanakan tradisi upacara mambilang hari, akan tetapi terdapat upacara malapeh-lapeh yang tidak dilakukan di tempat lain.

Malapeh-lapeh merupakan suatu upacara kematian dalam masyarakat di Nagari Taluak. Upacara kematian malapeh-lapeh dilakukan secara bersama dengan anggota keluarga dan warga kampung, serta memanjatkan doa bersama. Masyarakat Nagari Taluak percaya setelah melaksanakan tradisi malapeh-lapeh, roh orang yang telah meninggal dunia akan kembali dengan tenang ke alamnya. Pelaksanaan upacara kematian malapeh-lapeh pada setelah seratus hari mayat dikuburkan. Upacara malapeh-lapeh dilaksanakan pada kamis malam setelah shalat Isya. Menurut kepercayaan masyarakat setempat, pada kamis malam roh orang yang telah meninggal akan kembali ke dunia, dan berada di sekitar lingkungan rumah keluarganya. Doa bersama ini dilakukan oleh laki-laki, sedangkan yang perempuan membantu tuan rumah menghidangkan makanan yang akan disajikan.

Hingga kini sebagian besar warga masyarakat Taluak melaksanakan upacara malapehlapeh, karena dianggap sebagai upacara kematian yang penting oleh warga setempat. Upacara malapeh-lapeh sudah dilakukan secara turun temurun dan masih dilakukan sampai sekarang. Biaya yang dikeluarkan dalam upacara malapeh-lapeh sekitar Rp. 5.000.000. Biaya ini dipergunakan untuk menyiapkan hidangan makanan, dan sedekah kepada orang yang datang pada saat malapeh-lapeh. Besar biaya dalam pelaksanaan malapeh-lapeh tidak membuat masyarakat merasa terbebani, meskipun mereka terkategorikan miskin.

Beberapa penelitian telah mengungkap mengenai upacara kematian dan Islam (Virdiani, 2008; Widuri, 2015; Zakaria, 2012; Saputri, 2019; Mita, 2019). Penelitian lain juga mengungkap berbagai makna dari upacara kematian yang dilakukan oleh masyarakat (Trisa, 2011; Junita, 2016). Namun penelitian mengenai makna upacara kematian bagi masyarakat pendukung kebudayaan tetap menjadi penting karena keunikan kebudayaan masyarakat yang beragam dan perlu dipahami lebih jauh supaya tidak terjadi kesalah pahaman. Penelitian ini bertujuan mendeskripsikan dan menjelaskan makna upacara malapeh-lapeh bagi masyarakat di Nagari Taluak Kecamatan Batang Kapas Kabupaten Pesisir Selatan. Secara akademis, penelitian yang dilakukan menyumbang kajian Sosiologi Antropologi dalam mengembangkan materi Pendidikan Sosiologi Antropologi khususnya Antropologi Religi. Secara praktis, sebagai referensi untuk pembaca khususnya tentang upacara malapeh-lapeh di Nagari Taluak Kecamatan Batang Kapas Kabupaten Pesisir Selatan.

Dari sudut pandang Interpretivisme simbolik, fenomena upacara kematian dapat diamati dengan memahami simbol dan makna yang ada dalam pelaksanaan upacara. Simbol adalah objek, kejadian, bunyi bicara, atau bentuk-bentuk tertulis yang diberi makna oleh manusia. Bentuk primer dari simbolisasi oleh manusia adalah melalui bahasa. Tetapi, manusia juga komunikasi dengan menggunakan tanda dan simbol dalam lukisan, tarian, musik, arsitektur, mimik wajah, gerak gerik, postur tubuh, perhisan, pakaian, ritus, agama, kekerabatan, nasionalitas, tata ruang, pemilikan barang, setiap kejadian, tindakan, atau objek yang berkaitan dengan pikiran, gagasan dan emosi (Syaifuddin, 2006). Menurut Cifford Geertz kebudayaan adalah suatu pola makna makna yang diteruskan secara historis, yang terwujud dalam simbolsimbol, suatu sistem konsep yang diwariskan yang terungkap dalam bentuk bentuk simbolisyang dengannya manusia berkomunikasi, melestraikan dan mengembangkan pengetahuan mereka tentang kehidupan dan sikap-sikap tentang kehidupan (Syaifuddin, 2006). Dengan demikian, untuk memahami makna dari upacara malapeh-lapeh, perlu ditelusuri simbol-simbol dan maknanya bagi masyarakat Nagari Taluak. Upacara kematian malapeh-lapeh merupakan wujud dari kebudayaan yang dimiliki oleh masyarakat, dan penting dipahami maknanya. Makna dari upacara ini, telah ditanamkan sejak dahulunya oleh nenek moyang masyarakat nagari dan masih lestari sampai saat penelitian.

Culture \& Society: Journal of Anthropological Research Vol. 1, No. 3, Th. 2020 
Secara konseptual, upacara kematian merupakan bentuk kegiatan manusia dalam hidup bermasyarakat yang didorong oleh hasrat untuk mencari keselamatan dengan memnuhi tata cara yang ditradisikan dalam masyarakat. Hertz menyatakan bahwa upacara kematian selalu dilakukan manusia dalam rangka adat-istiadat dan struktur sosial dari masyarakat yang terwujud sebagai gagasan kolektif (Koentjaraningrat, 1987). Dalam pelaksanaan upacara kematian, biasanya selalu ada ritual atau ritus yang dilakukan oleh masyarakat yang berkaitan dengan pemaham agama. Ritual kematian mengikuti pemikiran antropolog Van Gennep dibagi dalam tiga tahapan yaitu (1) perpisahan atau separation, yaitu manusia melepaskan kedudukan semula. (2) peralihan atau marge,yaitu manusia dianggap mati atau" tidak ada" lagi dan dalam keadaan ini tak tergolong dalam lingkungan sosial manapun. (3) integrasi atau agregation yaitu manusia diresmikan dalam tahap kehidupan dan lingkungan sosialnya yang baru (Van Baal, 1988). Dalam penelitian ini dipahami makna simbol dari upacara kematian malapeh-lapeh menurut masyarakat lakal. Kata malapeh-lapeh dalam kosa kata bahasa Minangkabau berarti lepas atau melepaskan (Hans Lapaliwa, 1982). Dalam artian ini perlu dijelaskan apa makna dari kata malapeh secara bahasa ini menurut masyarakat Nagari Taluak ini.

\section{Metode Penelitian}

Penelitian ini termasuk penelitian etnografi, dimana peneliti terjun ke lapangan langsung, tinggal di lokasi penelitian selama tiga bulan. Melalui pendekatan ini peneliti dapat memperolah informasi secara langsung dari pihak yang terkait untuk memahami makna malapeh-lapeh orang meninggal pada masyarakat di Nagari Taluak. Pendekatan ini dipilih dengan pertimbangan bersifat fleksibel, luwes, dan terbuka kemungkinan bagi suatu perubahan dan penyesuaian penyesuaian ketika proses penelitian berjalan (Bungin, 2010). Informan penelitian dipilih secara sengaja (purposive sampling), dalam artian peneliti menentukan informan berdasarkan tujuan penelitian. Teknik ini dipilih, karena peneliti sudah memahami kriteria informan yang relevan untuk diminta informasi berhubungan dengan pokok persoalan yang diteliti. Adapun kriteria informan adalah: orang yang melaksanakan malapeh-lapeh dan elite tradisional setempat yang terdiri dari niniak mamak, alim ulama, candiak pandai, dan bundo kanduang serta warga masyarakat Nagari Taluak yang terlibat. Jumlah informan keselurah adalah 30 orang.

Teknik pengumpulan data dilakukan melalui observasi partisipasi dan wawancara mendalam. Pengamatan dilakukan terhadap simbol dari malapeh-lapeh. Kemudian melakukan wawancara mendalam kepada masyrakat yang terlibat pada saat malapeh-lapeh untuk mendapatkan informasi mengenai makna dari simbol. Untuk mendapat keabsahan data dilakukan triangulasi. Data yang sama dikumpulkan dari objek yang berbeda. Triangulasi yang digunakan yaitu triangulasi sumber. Data yang diperoleh dianalisis dengan mengacu pada model analisis interpretatif dengan langkah-langkah hermeneutik data, menginterpretasikan data, dan interpretatif direpresentasikan.

\section{Hasil dan Pembahasan}

\section{Gambaran Nagari Taluak}

Nagari Taluak merupakan salah satu nagari yang terdapat di Kecamatan Batang Kapas, Kabupaten Pesisir Selatan, Provinsi Sumatera Barat, Indonesia. Batas wilayah Nagari Taluak sebelah utara dengan Nagari Koto Nan Tigo, di sebelah selatan Nagari Taratak, di sebelah timur Nagari Taluk Tigo Sakoto, dan di sebelah barat Samudera Indonesia. Nagari ini terdiri dari daerah daratan dan pantai dengan suhu rata rata harian sekitar 27-32 derajat Celcius.

Secara demografis, jumlah penduduk nagari Taluak pada tahun 2017 yaitu 1.445 orang berjenis kelamin laki-laki dan 1.492 orang berjenis kelamin perempuan. Dari jumlah penduduk secara keseluruhan, $163 \mathrm{KK}$ termasuk ke dalam keluarga prasejahtera, $63 \mathrm{KK}$ dikategorikan sejahtera I, $50 \mathrm{KK}$ dikategorikan sejahtera II, $320 \mathrm{KK}$ dikategorikan sejahtera III, dan $128 \mathrm{KK}$ dikategorikan sejahtera III plus. Dari data terlihat masih banyak keluarga yang masuk ke dalam keluarga miskin. Mata pencaharian utama adalah sebagai nelayan dan petani peladang. Dari

Culture \& Society: Journal of Anthropological Research Vol. 1, No. 3, Th. 2020 
segi pendidikan masyarakat nagari Taluak dikategorikan pendidikan yang cukup tinggi karena telah ada yang tamat SMA dan Perguruan Tinggi. Agama yang dianut oleh masyarakat adalah Islam. Sejalan dengan adat istiadat Minangkabau, adat basandi syara, syarak basandi katabullah.

\section{Proses Upacara Kematian Malapeh-lapeh}

Upacara kematian malapeh-lapeh dilaksanakan setelah tradisi upacara kamatian manyaratuih hari. Masyarakat biasa melaksanakan upacara ini pada hari kamis malam setelah shalat isya. Tempat pelaksanaan acara yaitu di rumah keluarga yang meninggal. Hingga kini sebagian besar warga masyarakat Taluak melaksanakan upacara malapeh-lapeh, karena dianggap sebagai upacara kematian yang penting oleh warga setempat. Hal ini terlihat jika masyarakat tidak mampu melaksanakan malapeh-lapeh dalam waktu yang ditentukan, maka diperbolehkan pelaksanaannya diundur sampai biaya untuk malapeh-lapeh ini mencukupi ${ }^{1}$. Dengan kata lain, ahli bait harus tetap melaksanakan upacara malapeh-lapeh untuk anggota keluarganya yang telah meninggal dunia.

Persiapan upacara malapeh-lapeh, pertama yaitu menyiapkan rumah dengan atribut seperti kain langik-langik yaitu kain yang digunakan sebagai penutup loteng, kain ini juga biasa dipakai ketika upacara. Perbedaannya kain langik-langik yang digunakan untuk upacara perkawinan, kain langik-langik memiliki motif yang lebih meriah dan banyak, serta pemasangan kain langiklangik di setiap sudut rumah. Sedangkan untuk upacara kematian, kain langik-langik dipilih dengan motif yang lebih sederhana, serta digunakan di atas tempat mayat terbujur. Selanjutnya pemasangan kain tabie sebagai penutup dinding. Pemasangan tabie dan kain langik- langik dilakukan secara bergotong royong bersama kerabat dan juga tetangga pihak keluarga yang meninggal. Selanjutnya juga dipersiapkan oleh keluarga alat dan bahan untuk membuat lemang, harum-haruman yang terbuat dari daun pandan dan bunga yang dimasukkan kedalam ketupat, dan bahan makanan sebagai hidangan mandoa (selamatan). Sehari sebelum acara semua warga sudah diundang untuk menghadiri acara ini.

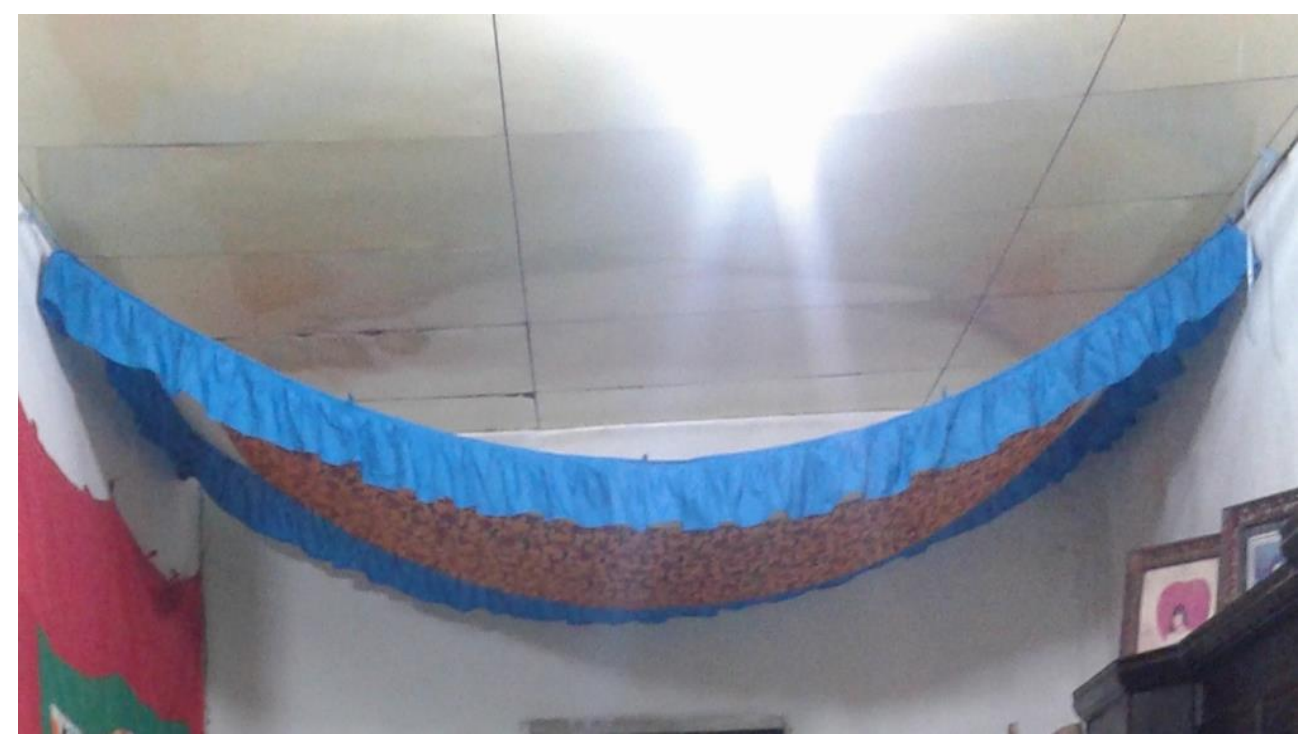

Gambar 1. Kain Langik-langik

\footnotetext{
${ }^{1}$ Saipul (60 tahun) wawancara dilakukan pada tanggal 08 Februari 2018 di rumah beliau, merupakan salah satu siak labai dalam masyarkat. $\mathrm{Hal}$ ini juga diungkap oleh Minus (67 tahun) wawancara dilakukan pada tanggal 09 Juli 2018 di rumah beliau, merupakan bundo kanduang di Nagari Taluak. Opet (48 tahun) wawancara dilakukan pada tanggal 02 Juli 2018 di rumah beliau, merupakan bundo kanduang di Nagari Taluak.
}

Culture \& Society: Journal of Anthropological Research Vol. 1, No. 3, Th. 2020 


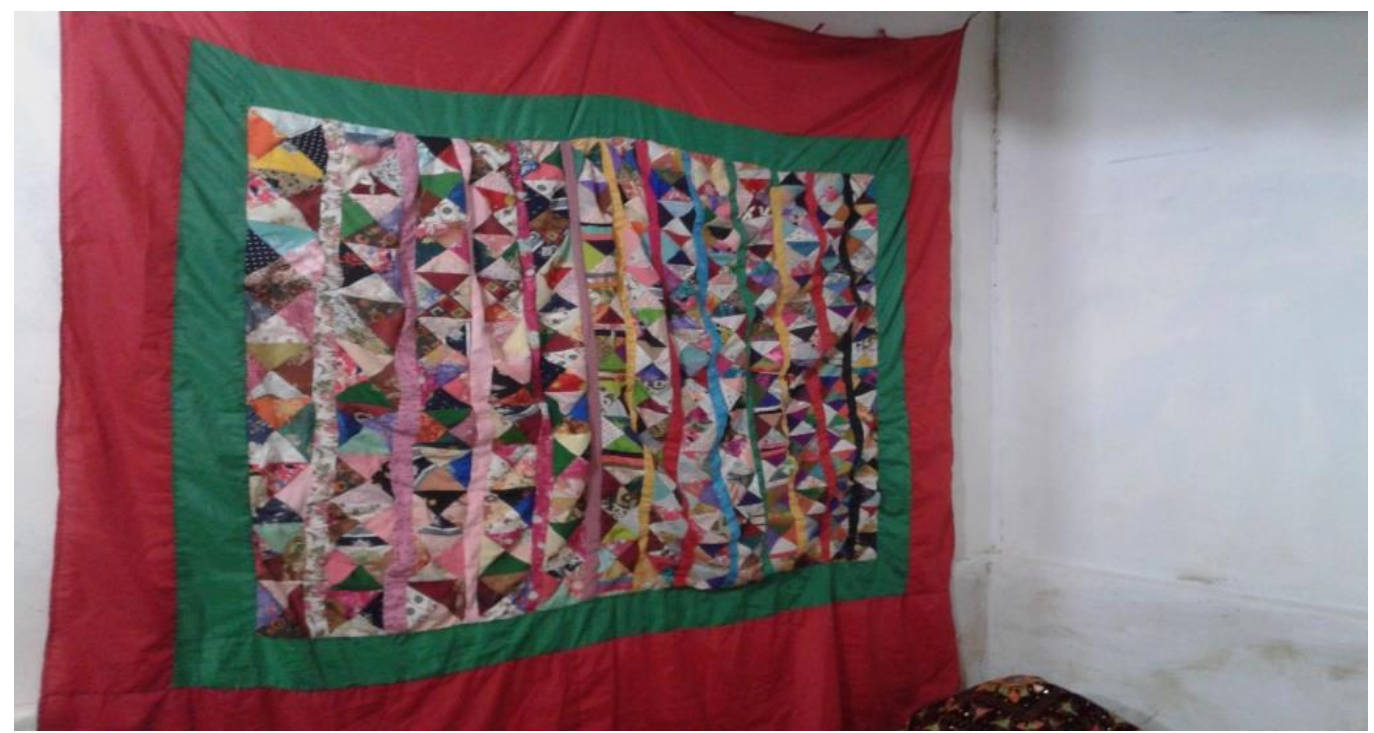

Gambar 2. Kain tabie

Pelaksanaan upacara malapeh-lapeh pertama dibuka oleh yang punya acara (sipanka) dengan pidato singkat. Pidato yang disampaikan intinya adalah menyampaikan tujuan dilakukan acara yaitu untuk meminta pada yang hadir mendoakan supaya yang meninggal dilapangkan kubirnya dan ditempatkan ditempat orang yang beriman. Selanjutnya yaitu pengajian dan tahlil yang dilakukan oleh laki-laki, yang memimpin upacara ini disebut dengan orang siak labai. setelah tahlil maka anggota pengajian makan bersama, dilanjutkan dengan dzikir dan diakhir dengan sedekah dari pihak keluarga yang meninggal. Sewaktu dilakukan dzikir bersama salah seorang anggota keluarga akan mendekati peserta dzikir dan menyelipkan ketupat yang berisi wangi-wangian yang terbuat dari daun pandan dan bunga-bungan ke tangan anggota dzikir.

Pada acara makan bersama terdapat yang menarik disini, yaitu adanya makanan dalam acara ini selain disediakan oleh tuan rumah, juga berasal dari keluarga terdekat orang yang meninggal, seperti istri paman, bako,dan istri anak laki-laki (manantu). Jenis makanan yang dibawa oleh keluarga terdekat itu tidak ditentukan, melainkan jenis dan jumlahnya disesuaikan dengan kemampuan ekonomi keluarga terkait. Makan bersama dianggap sebagai sedekah keluarga kepada orang yang hadir saat upacara malapeh-lapeh dilaksanakan. Berikut adalah contoh makanan dari bako Sari Ambo dan menantu:

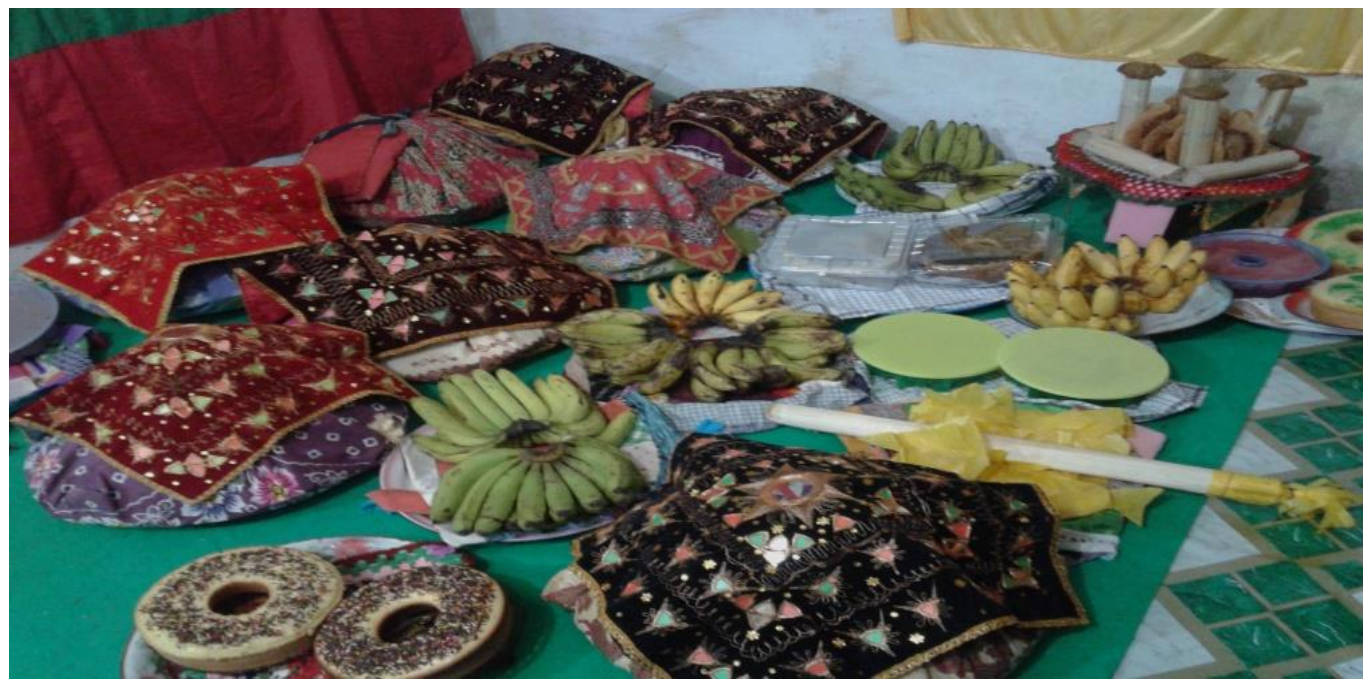

Gambar 3. Hantaran dari Bako

Culture \& Society: Journal of Anthropological Research Vol. 1, No. 3, Th. 2020 
Selain itu pihak keluarga juga menyiapkan lemang yang diberikan kepada siak labai. Ada dua jenis lemang, pertama, lemang tagak dan kedua, satu batang. Lemang tagak khusus jika yang meninggal sudah memiliki menantu dan dibauat oleh keluarga besan. Di bawah ini bentuk lemang tersebut:

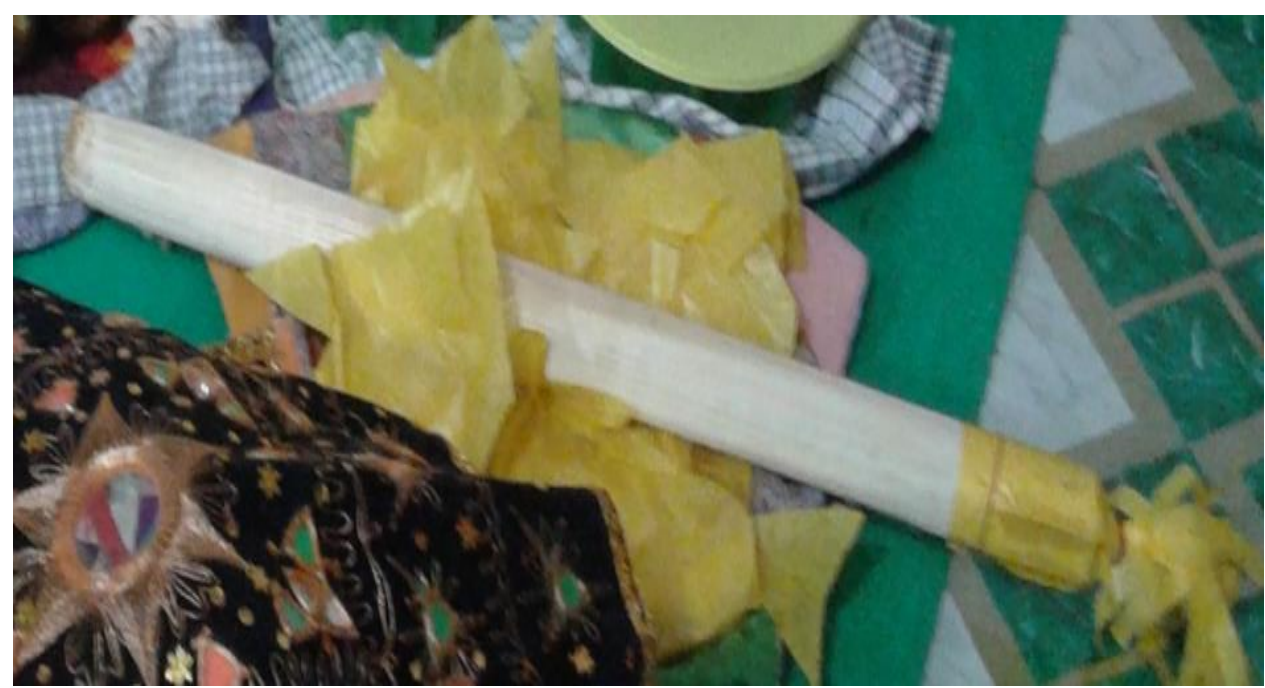

Gambar 4. Lamang satu batang

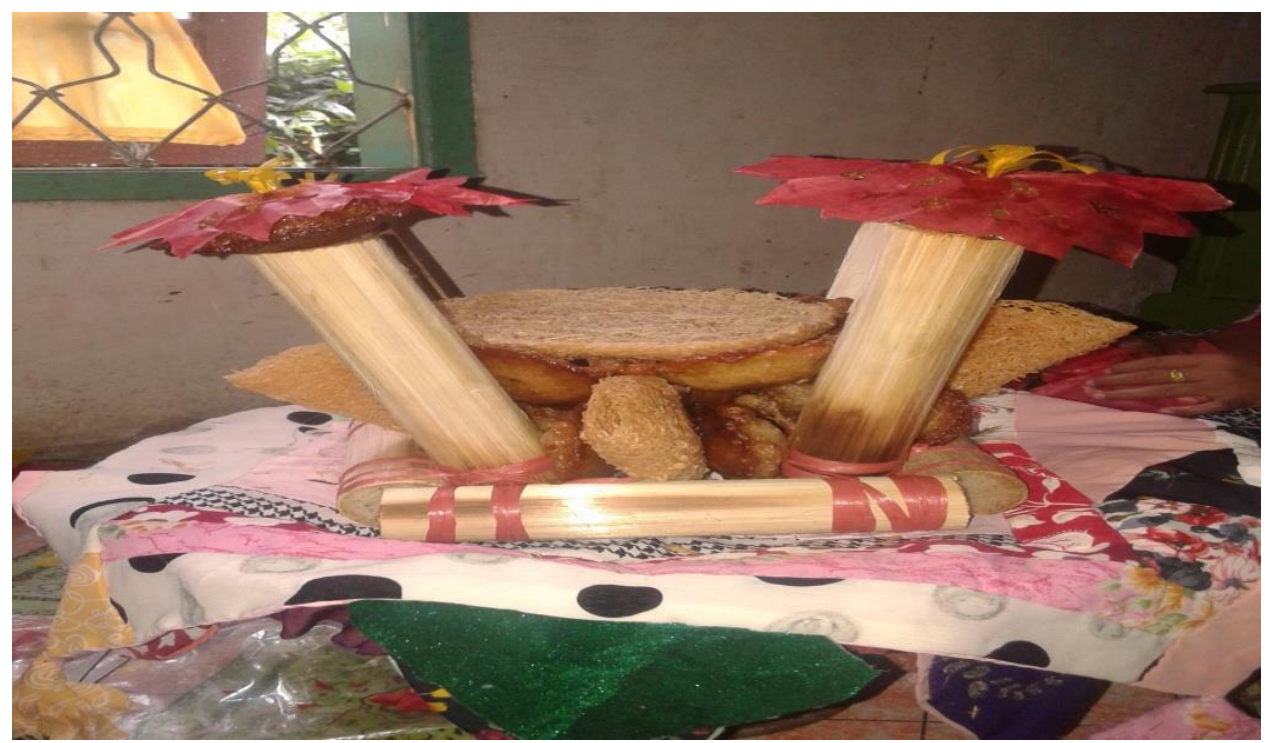

Gambar 5. Lamang Tagak

Kegiatan penutup dari upacara malapeh-lapeh yaitu tuan rumah memberikan sedekah kepada undangan yang hadir. Cara pembagian sedekah saat malapeh-lapeh ini berbeda antara laki-laki yang mengikuti acara dalam malapeh-lapeh dengan perempuan dan anak-anak yang tidak ikut acara malapeh-lapeh. Laki-laki yang mengikuti acara malapeh-lapeh, sedekah diberikan saat basanji dzikir bersama. Dua orang sumando akan berkeliling mengunjungi warga masyarakat, satu orang membawa anyaman ketupat yang berisi harum-haruman dan satu orang lagi membawa uang untuk disedekahkan. Setelah selesai, dilanjutkan dengan pidato penutup dari tuan rumah, warga masyarakat yang hadir dan tuan rumah pun sepakat acara malapeh-lapeh selesai diadakan. Maka acara malapeh-lapeh diakhiri dan ditutup dengan mengucapkan alhamdulillah dan doa penutup majelis. 


\section{Makna Upacara Kematian Malapeh-lapeh}

\section{Penghargaan Status Niniak Mamak}

Niniak mamak dalam kebudayaan Minangkabau memiliki peran dan fungsi yang cukup sentral. Niniak mamak atau disebut juga saudara laki-laki ibu, dan saudara laki-laki nenek dari keluarga perempuan. Dalam hal ini, masyarakat sangat menghargai status yang dimiliki seseorang dalam masyarakat. Hal ini terlihat pada saat pelaksanaan upacara malapeh-lapeh, niniak mamak orang meninggal yang hadir akan ditempatkan duduk di bawah kain langik-langik dan bersandar pada kain tabie. Masyarakat Taluak yang bukan niniak mamak tidak akan duduk pada posisi tersebut. Artinya, masyarakat sudah memahami pemasangan kain langik-langik dan kain tabie saat pelaksanaan upacara malapeh-lapeh, selain sebagai simbol dari pelaksanaan upacara malapeh-lapeh itu sendiri, juga sebagai tanda penghargaan terhadap niniak mamak. Makna dari kain langik-langik ini diungkapkan oleh Syafrizal (58 tahun) ${ }^{2}$ sebagai berikut:

Kain langik-langik untuk pada upacara kematian digunakan di atas mayat sebagai penutup. Sedangkan dalam upacara malapeh-lapeh, kain langik-langik sebagai tempat niniak mamak duduk saat pelaksanaan upacara kematian. Sebagai rasa menghargai niniak mamak dalam adat. Sehingga masyarakat sudah mengetahui bahwa kain langik-langik digunakan saat upacara kematian sebagai salah satu cara menghargai niniak mamak.

Sedangkan kain tabie memiliki makna sebagai menghargai niniak mamak juga diungkapkan oleh saipul (60 tahun) $)^{3}$.

Kain tabie digunakan saat malapeh-lapeh untuk menghargai niniak mamak yang hadir pada saat pelaksanaan malapeh-lapeh. Kain tabie diletakkan dekat dengan kain langiklangik. Niniak mamak akan duduk tepat dibawah kain langik-langik dan bersandar pada kain tabie. Selain itu juga adanya kain tabie sebagai cara dari tuan rumah untuk menghargai kedatangan niniak mamak. Jika kain tabie dan kain langik-langik digunakan saat malapeh-lapeh, harus ada sekapur sirih. Sedangkan jika kain tabie dan kain langik-langki tidak digunakan saat malapeh-lapeh tidak masalah sekapur sirih tidak ada. Tapi jika kain tabie dan kain langik-langik digunakan saat malapeh-lapeh maka sakapur sirih wajib ada. Karena mereka tidak boleh dipisahkan.

Berdasarkan hasil wawancara dan observasi yang dilakukan oleh peneliti bahwa penghargaan status dari keluarga duka untuk niniak mamak dalam pelaksanaan malapeh-lapeh masih sangat terlihat terjelas. Hal ini terlihat oleh peneliti saat melakukan observasi bahwa masyarakat yang bukan niniak mamak dari keluarga yang meninggal, mereka tidak akan duduk di bawah kain langik-langik dan tidak bersandar pada kain tabie.

\section{Solidaritas sosial dalam masyarakat}

Hubungan kekerabatan dalam pelaksanaan malapeh-lapeh ini sangat berperan penting. Hal ini terlihat dari makanan yang dibawakan pihak bako orang yang meninggal untuk makan bersama. Hubungan kekerabatan ini juga ternyata dipengaruhi oleh faktor ekonomi, jika pihak bako orang yang meninggal dikategorikan mampu maka makanan yang dibawa untuk makan bersama beragam. Namun sebaliknya, jika pihak bako dikategorikan biasa atau kurang mampu,

\footnotetext{
${ }^{2}$ Syafrizal (58 tahun) wawancara dilakukan pada tanggal 14 Juli 2018 dirumah beliau, merupakan niniak mamak di Nagari Taluak. Hal ini juga diungkap oleh Saraini (60 tahun) wawancara dilakukan pada tanggal 07 Juli 2018 di rumah beliau, merupakan salah satu masyarakat yang melaksanakan malapeh-lapeh.

3 Saipul (60 tahun) wawancara dilakukan pada tanggal 14 Juli 2018 di rumah beliau, merupakan siak labai di Nagari Taluak. Hal ini juga diungkap oleh Icap (58 tahun) wawancara dilakukan dilakukan pada tanggal 16 Juli 2018 dirumah beliau, merupakan niniak mamak di Nagari Taluak.
}

Culture \& Society: Journal of Anthropological Research Vol. 1, No. 3, Th. 2020 
maka makanan yang dibawa untuk makan bersama juga disesuaikan dengan kemampuan ekonomi. Hal ini diungkap oleh Limarni.

\begin{abstract}
Makanan hidangan yang dibawakan oleh pihak bako orang yang meninggal tidak sama antara satu dengan yang lainnya. Hal ini karena dipengaruhi oleh keadaan ekonomi. Jika pihak bako dikategorikan mampu, maka hidangan yang akan dibawa banyak, tapi sebaliknya jika pihak bako ini sederhana maka yang dibawa juga semampunya saja. Hidangan ini bertujuan untuk membantu tuan rumah dalam menyiapkan makanan yang akan dimakan bersama-bersama.
\end{abstract}

Hubungan kekerabatan ini terlihat juga dari pihak menantu, jika orang yang meninggal telah memilki menantu, maka menantu tersebut wajib membawa lamang tagak. Ini sudah menjadi sebuah keharusan di dalam masyarakat Taluak, dan masih dilaksanakan sampai saat sekarang. Lamang tagak memiliki makna yang di pahami oleh masyarakat Taluak, adapun makna dari lamang diungkapkan oleh Syafrizal (58 tahun) ${ }^{4}$.

Lamang tagak ini berbeda dengan lamang yang akan diberikan untuk siak labai. Lamang tagak dibuat oleh menantu orang yang sudah meninggal, dan sebagai lambang kalau yang meninggal memiliki menantu. Lamang tagak terdiri dari empat tiang, masing-masing tiang memiliki arti. Tiang pertama melambangkan agama, tiang ke dua melambangkan adat, tiang ke tiga melambangkan hukum, dan tiang yang ke empat melambangkan pengetahuan. Lamang tagak harus terdiri dari empat tiang, tidak boleh lebih dan tidak boleh kurang. Jika tidak sesuai, maka yang akan malu adalah niniak mamak. Sebelum disusun menjadi empat tiang, lamang tagak juga diletakkan beberapa lamang sebagai pondasi.

Berdasarkan hasil penelitian, wawancara dan observasi yang dilakukan peneliti pada masyarakat Taluak bahwa bako sangat berperan penting dalam setiap acara adat yang dilaksanakan. Hal itu juga terlihat pada saat upacara malapeh-lapeh dilaksanakan.

\title{
Identitas Masyarakat
}

Malapeh-lapeh ini sendiri sudah bisa dikatakan sebagai identitas dari masyarakat Taluak. Bagi masyarakat, jika seseorang tidak melaksanakan malapeh-lapeh maka meninggal akan dikatakan sama seperti mati seekor hewan. selain itu, malapeh-lapeh juga dijadikan sebagai salah satu tolak ukur masyarakat sempurna tidaknya seseorang dalam melaksanakan adat di Nagari Taluak.

Untuk melaksanakan upacara malapeh-lapeh masyarakat Nagari Taluak tidak terhambat oleh keadaan ekonomi. Bahkan sebagian masyarakat rela berhutang kepada orang lain untuk pelaksanaan upacara malapeh-lapeh ini $^{5}$. Hal ini dilakukan agar keluarganya tidak mendapatkan sanksi sosial dari masyarakat. Selain itu, upacara malapeh-lapeh hanya dilaksanakan di Nagari Taluak, daerah sekitar Nagari Taluak seperti di Kota Painan maupun nagari yang berada di sekitar Nagari Taluak warga tidak melaksanakan malapeh-lapeh ${ }^{6}$.

\section{Keyakinan agama, bahwa pahala mengalir kepada orang yang meninggal}

Lamang dan lamang tagak. Lamang merupakan makanan wajib yang harus ada pada saat pelaksanaan malapeh-lapeh. Lamang ini terbuat dari beras pulut putih yang masak di dalam bambu. Lamang ini oleh masyarakat dibagi menjadi dua, yaitu lamang yang akan diberikan untuk

\footnotetext{
4 Syafrizal (58 tahun) wawancara dilakukan pada tanggal 16 Juli 2018 di rumah beliau, merupakan niniak mamak di Nagari Taluak. Hal ini juga diungkap oleh Saipul (60 tahun) wawancara dilakukan dilakukan pada tanggal 14 Juli 2018 dirumah beliau, merupakan siak labai di Nagari Taluak. Katik Kamba (55 tahun) wawancara dilakukan pada tanggal 13 Juli dirumah beliau, merupakan siak labai di Nagari Taluak.

5 Yul (55 tahun) wawancara dilakukan pada tanggal 01 Juli 2018 di Kantor Wali Nagari Taluak, merupakan sekretaris Nagari Taluak

${ }^{6}$ Saipul (60 tahun) wawancara dilakukan pada tanggal 08 Februari 2018 di rumah beliau, merupakan siak labai di Nagari Taluak.
}

Culture \& Society: Journal of Anthropological Research Vol. 1, No. 3, Th. 2020 
siak labai yang telah memimpin doa saat upacara malapeh-lapeh, dan lamang yang dibuat oleh menantu almarhum. Sedangkan lamang tagak yang ada pada saat pelaksanaan malapeh-lapeh ini, sebagai tanda bahwa orang yang meninggal tersebut sudah memiliki menantu. lamang tagak ini hanya dibawakan oleh menantu saja. Lamang tagak terdiri dari empat tiang, dan masing-masing tiang tersebut memiliki arti tersendiri dalam masyarakat. Tiang pertama melambangkan agama, tiang ke dua melambangkan adat istiadat, tiang ketiga melambangkan hukum, dan tiang yang terakhir melambangkan pengetahuan.

Pengajian atau tahlil. Makna pengajian atau tahlil yang dilakukan oleh masyarakat dalam pelaksanaan upacara malapeh-lapeh, sebagai permohonan yang ditujukan kepada orang sudah meninggal agar kuburnya dilapangkan dan diberikan kelancaran menuju alam yang kekal, begitu juga dengan aktivitas dzikir dan basanji. Pelaksanaan dzikir saat malapeh-lapeh ini dibagi menjadi dua bagian, yaitu pertama, disebut dengan dzikir. Sedangkan yang kedua disebut dengan pembacaan shalawat nabi atau masyarakat menyebut basanji. Terdapat perbedaan dalam pelaksanaan dzikir dan pelaksanaan basanji saat malapeh-lapeh. Dzikir dilakukan oleh laki-laki dengan duduk bersila ditempat, sedangkan basanji dilakukan dengan berdiri dan melipatkan kedua tangan. Makna dzikir dan basanji bagi masyarakat Taluak sama halnya dengan pengajian dan tahlil. Tujuannya yaitu untuk mendoakan orang sudah meninggal untuk tenang dan bahagia di alamnya.

Aktivitas Sedekah pihak keluarga orang yang meninggal memberikan uang kepada orang yang hadir saat malapeh-lapeh dilaksanakan. Makna dari pembagian sedekah ini bagi masyarakat Taluak yaitu, pahala dari yang disedahkan itu ditujukan untuk orang yang sudah meninggal. Semakin banyak uang yang disedekahkan, maka semakin banyak pula pahala yang akan di peroleh orang sudah meninggal tersebut. Namun jumlah uang yang disedekah kan ini tentu sesuai dengan keadaan ekonomi dari keluarga orang yang sudah meninggal. Jika keluarganya dikategorikan mampu, maka nominal sedekahnya juga akan lebih banyak, tapi sebaliknya jika keadaan ekonomi keluarga tersebut sederhana maka nominal sedekah disesuaikan dengan kemampuan ekonomi tersebut.

\section{Kesimpulan}

Dari hasil penelitian dapat dinyatakan bahwa malapeh-lapeh dalam upacara kematian memiliki arti penting dan makna bagi masyarakat Taluak. Makna oleh masyarakat tersebut ditafsirkan (native point of view) keseluruhan simbol dalam upacara kematian malapeh-lapeh memiliki makna. Beberapa makna di dalam upacara malapeh-lapeh yaitu, makna simbol benda yang ada saat pelaksanaan, makna kegiatan dalam upacara malapeh-lapeh, dan makna waktu pelaksanaan. Makna etik ditarik berdasarkan makna emik (interpretative direpresentasikan) yaitu (1) Penghargaan status niniak mamak dari keluarga duka. Bagi masyarakat Taluak, status seseorang sangat dihargai apalagi sebuah status dalam adat. Dalam hal ini penghargaan niniak mamak sangat terasa pada saat malapeh-lapeh, untuk niniak mamak yang hadir posisi duduknya tepat dibawah kain langik-langik dan bersandar pada kain tabie. Selain daripada itu dalam aktivitas pemberian daro pihak bako, menantu berupa makanan menunjukkan status dan hubungan kekerabatan diantara keluarga yang sekerabat karena ikatan tali darahbdan ikatan perkawinan, dan ikatan itu semakin terlihat dalam upacara. (2) Solidaritas Sosial dalam masyarakat. Dalam hal ini sangat terlihat adalah pihak bako dan menantu dari orang yang meninggal. Bako membawa makanan untuk makan bersama, sedangkan menantu membawa lamang tagak sebagai tanda. (3) Sebagai salah satu bentuk menunjukkan identitas masyarkat. Masyarakat Taluak yang melaksanakan malapeh-lapeh sebagai penutup rangkaian dari upacara kematian di dalam masyarakat. Masyarakat tetap melaksanakan malapeh-lapeh ini sebagai warisan dari nenek moyang yang harus tetap diturunkan secara turun-temurun dari generasi ke generasi berikutnya. Malapeh-lapeh ini memiliki arti penting bagi masyarakat, bahkan masyarakat rela berhutang agar pelaksanaan malapeh-malapeh dapat dilaksanakan. Masyarakat yang tidak melaksanakan malapeh-lapeh meninggalnya dianggap sama dengan matinya seekor hewan.

Culture \& Society: Journal of Anthropological Research Vol. 1, No. 3, Th. 2020 


\section{Daftar Pustaka}

Agus, B. (2006). Pengantar Antropologi Agama. Jakarta: PT Raja Grafindo Persada

Baal, V. (1988). Sejarah dan Pertumbuhan Teori Antropologi Budaya. Jakarta: PT Gramedia

Bungin, B. (2010). Analisis Data Penelitian Kualitatif. Jakarta: PT Raja Grafindo Persada

Fauzi, MI. (2014). Tradisi Tahlilan dalam Kehidupan Masyarakat Desa Tegalangus (Analisis Sosio Kultural)". repository.uinjkt.ac.id/dspace/.../3/MUHAMMAD\% 20IQBAL\%20 FAUZI-FITK.pdf. Diakses pada 5 Februari 2018

Geertz, C. (1992). Tafsir Kebudayaan. Yogyakarta: Kanisius

Junita, E. (2016). Upacara Kematian Saurmatua pada Adat Masyarakat Batak Toba (Studi Kasus: Persiapan Keluarga) Kecamatan Purbatua Kabupaten Tapanuli". https://media.neliti.com/media/publication/33072-ID-upacara-kematian-saurmatuapada-adat-masyarakat-batak-toba-studi-kasus-tentang-k.pdf Diakses pada 5 Februari 2018

Koentjaraningrat, K. (1987). Sejarah Antropologi I. Jakarta: Universitas Indonesia Press

Mita, M., Fitriani, E., \& Hasti Hasmira, M. (2019). Manyanda: Studi Struktural Fungsional Manyanda di Nagari Talang Kabupaten Solok. Jurnal Perspektif, 2(3), 206-214. doi:10.24036/perspektif.v2i3.91

Saifuddin, AF. (2006). Antropologi Kontemporer. Jakarta: Kencana

Saputri, D., \& Fitriani, E. (2019). Fungsi Labai dalam Upacara Kematian di Nagari Sungai Durian. Jurnal Perspektif, 2(1), 20-27. doi:10.24036/perspektif.v2i1.63

Trisa, Y. (2011). Tradisi Manjanguak Mantah dan Manjanguak Masak dalam Upacara Kematian di Nagari Tandikek. Skripsi. Universitas Negeri Padang

Virdiani, Zul. (2008). Tradisi Peringatan (Slametan) Sesudah Kematian Seseorang di Tinjau dari Hukum Islam Desa Sroyo Kecamatan Jaten Kabupaten Karanganyar. Eprints.ums.ac.id/4126/2/c100040103.pdf. Diakses pada 5 Februari 2018

Widuri, DP. (2015). Perubahan Sosial Tahlilan Selamatan Kematian di Dusun Kamijoro Desa Sendangsari Kecamatan Pajangan Kabupaten Bantul. Skripsi. UIN Sunan Kalijaga

Zakaria. (2012). Tradisi Tahlil Masyarakat Kabupaten Cirebon repository.syekhnurjati.ac.id/ 1541/1/ZAKARIA 58110031 OK.pdf Diakses pada 5 Februari 2018

Zul, V. (2008). Tradisi Peringatan (Slametan) Sesudah Kematian Seseorang di Tinjau dari Hukum Islam Desa Sroyo Kecamatan Jaten Kabupaten Karanganyar. Eprints.ums.ac.id/4126/2/c100040103.pdf Diakses pada 5 Februari 2018 